\title{
A geochemical modelling study of the evolution of the chemical composition of seawater linked to a "snowball" glaciation
}

\author{
G. Le Hir ${ }^{1}$, Y. Goddéris ${ }^{2}$, Y. Donnadieu ${ }^{1}$, and G. Ramstein ${ }^{1}$ \\ ${ }^{1}$ LSCE, CNRS-CEA-UVSQ, Gif-sur-Yvette, France \\ ${ }^{2}$ LMTG, CNRS, Observatoire Midi-Pyrénées, Toulouse, France
}

Received: 20 April 2007 - Published in Biogeosciences Discuss.: 20 June 2007

Revised: 29 November 2007 - Accepted: 18 January 2008 - Published: 21 February 2008

\begin{abstract}
The Snowball Earth theory initially proposed by Kirschvink (1992) to explain the Neoproterozoic glacial episodes, suggested that the Earth was fully ice-covered at $720 \mathrm{Ma}$ (Sturtian episode) and 640 Ma (Marinoan episode). This succession of extreme climatic crises induced environmental perturbations which are considered as a strong selective pressure on the evolution of life (Hoffman et al., 1998). Using a numerical model of carbon-alkalinity global cycles, we quantify environmental stresses caused by a global glaciation. According to our results, we suggest that during global glaciations, the ocean becomes acidic ( $\mathrm{pH} \sim 6)$, and undersaturated with respect to carbonate minerals. Moreover the quick transition from ice-house to greenhouse conditions implies an abrupt and large shift of the oceanic surface temperature which causes an extended hypoxia. The intense continental weathering, in the aftermath of the glaciation, deeply affects the seawater composition inducing rapid changes in terms of $\mathrm{pH}$ and alkalinity. We also propose a new timing for post glacial perturbations and for the cap carbonates deposition, $\sim 2 \mathrm{Myr}$ instead of $200 \mathrm{kyr}$ as suggested in a previous modelling study. In terms of Precambrian life sustainability, seawater $\mathrm{pH}$ modifications appear drastic all along the glaciation, but we suggest that the buffering action of the oceanic crust dissolution avoids a total collapse of biological productivity. But short-lived and large post-glacial perturbations are more critical and may have played the role of an environmental filter proposed in the classic snowball Earth theory. Although the link between environmental changes and life
\end{abstract}

Correspondence to: G. Le Hir

(Guillaume.Le-Hir@cea.fr) sustainability cannot be modelled accurately, we suggest that only a permissive life (Knoll, 2003) may explain the relative continuity in microfossils diversity observed before, during and after Neoproterozoic glaciation events.

\section{Introduction}

Oceans covered more than $75 \%$ of the Earth surface during the Neoproterozoic and were the only habitable environment for the Precambrian life. The history of the chemical composition of seawater is closely tied to the history of the atmosphere in terms of oxygen and carbon content, but also depends on the chemical signature of rivers entering the oceans and of hydrothermal fluids released in seawater along oceanic ridges. Reconstructions of the seawater composition during the geological past rely on indirect data from marine sedimentary rocks. In consequence the global deposition of carbonate layers overlapping Neoproterozoic glacial deposits and the return of iron formations suggest strong changes in seawater composition at the end of the Proterozoic era (Hoffman and Schrag, 2002, and references therein). This environmental perturbation seems to be closely related to a severe biological disturbance. Indeed carbon isotopic negative anomalies in postglacial carbonates (Hoffman et al., 1998) are commonly considered as the consequence of a biological productivity collapse. All geological features cited previously might be explained by a common origin: a global glaciation, also known as the "snowball Earth" event. However, the role of environmental filter played by global glaciation is still largely debated. On the

Published by Copernicus Publications on behalf of the European Geosciences Union. 
one hand, a fine microfossils study of Neoproterozoic glacial intervals reveals no marked microbiota perturbations before and after Neoproterozoic glaciations (Corsetti et al., 2003; Corsetti, 2006; Grey et al., 2003), in disagreement with the bottle-neck effect due to a global glaciation initially proposed (Hoffman et al., 1998), and suggesting the existence of a paradox between life continuity and extreme environmental changes. But this paradox is not obvious. Indeed, a recent fossil study of the Doushantuo Formation (Yin et al., 2007 and references therein) argues for strong evolutionary disturbances in the immediate post-glacial environment. Since the biological impact of the snowball events is still controversial, the quantification of the amplitude of the environmental changes occurring during and in the direct aftermath of a snowball event should be a milestone contribution. This is the aim of this work. Using a numerical model of the geochemical cycles we investigate the chemical composition of the seawater during these extreme glacial events and in their direct aftermath.

\section{Geological context and experimental design}

The aim of our study is to simulate the chemical evolution of the Proterozoic ocean all along the glaciation, and extending our modelling into post-glacial perturbations. To improve our knowledge of the ocean chemistry evolution during and after the glaciation, we build up a numerical model of the oceanic and atmospheric oxygen and carbon cycles, and alkalinity. Since our geochemical model considers a global ocean, our aim is to constraint large scale geochemical evolution of the ocean, without being able to jump into regional processes.

\subsection{Initial assumptions}

To investigate seawater perturbations during global glaciations, an important issue is to know whether the ocean remained in contact with the atmosphere during the whole glacial interval, or whether it was fully isolated. Patches of open water were proposed in the original Snowball Earth theory to keep the biosphere alive (Kirschvink, 1992), an hypothesis strengthened by the recent photosynthetic biomarkers discovery inside the glacial deposits (Olcott et al., 2005). Also air-sea gas exchanges, through cracks in the sea-ice took place during the glaciation (Hoffman et al., 1998). Since tiny area of open waters allow efficient gas exchanges between the atmosphere and ocean (Le Hir et al., 2008), a scenario with the ocean and atmosphere in equilibrium during the glaciation appears the most likely solution. However, as the previous assumption remains partly speculative, we have performed a simulation with an isolated ocean so that both scenarios can be compared (uncertainties and limitations section).
A main prescribed condition to simulate a global glaciation is the strong decrease in the continental weathering. In the snowball Earth theory, cold temperatures associated with extended land ice are required conditions to drop the continental silicate weathering, a fundamental condition to build up the very high volcanic $\mathrm{CO}_{2}$ into the atmosphere needed to trigger the deglaciation and produce the subsequent accumulation of the cap carbonates. The possible persistence of an active hydrological cycle and continental weathering during the Neoproterozoic glaciation have been proposed to explain the diamictites formation (Leather et al., 2002) and geochemical records of periodic high degree of alteration (Rieu et al., 2007). As demonstrated by Donnadieu et al. (2003), the existence of a dynamic ice cycle, and the sediments transport by ice movements (O Cofaigh et al., 2007), is not in contradiction with the existence of a thick continental icecap during the glacial event, forcing weathering to be extremely weak. Indeed, a dynamic ice cycle may be maintained through sublimation and ice formation only (Goodman and Pierrehumbert, 2003), without transient liquid water. Moreover, if a chemical weathering is maintained below glaciers, it is certainly extremely low (Tranter et al., 2002). Furthermore, during a snowball episode, predicted temperatures are extremely low and the runoff weak, even with 0.2 bar of $\mathrm{CO}_{2}$ (Pierrehumbert, 2005). For all these reasons, the existence of periods where the weathering remains efficient inside the Neoproterozoic glaciations contradicts the hard snowball Earth scenario (Rieu et al., 2007), because intense weathering requires large ice-free land surfaces and a relatively warm and humid climate. If Rieu et al. (2007) are right, and this may depend on the precise datation of the Fiq formation in Oman (radiometric age of the basis of the formation at $723+16 /-10$ $\mathrm{Ma}$, and guessed age of the top around $635 \mathrm{Ma}$ (Le Guerroue et al., 2007)), the snowball theory must be rethought, and this is beyond the scope of this contribution. Since such cold events suggest that chemical reactions were sufficiently slow to be neglected, we fix the continental weathering rate to zero during the glaciation.

If the ocean is not isolated from the atmosphere during the snowball Earth glaciation, chemical evolutions of the two exospheric compartments are intertwined. In the absence of an efficient continental weathering, the main processes changing the seawater composition are those occurring at the seawater - oceanic crust interface. If we assume that the average hydrothermal water flux is around $10^{13} \mathrm{~m}^{3} /$ year (Elderfield and Schultz, 1996) then the whole oceanic volume will circulate into the oceanic crust in less than 1 million years (Myr). Considering that the minimal snowball duration exceeds 4 Myr (Bodiselitsch et al., 2005), hydrothermal activity at mid-ocean ridges and low-temperature weathering of the oceanic crust silicates would largely affect the seawater composition. These processes are thus considered in our modelling study. Note that we assume the present day hydrothermal water flux from Elderfield and Schultz (1996) in the Neoproterozoic conditions. This is a common method 
Table 1. Kinetic dissolution constants in $\mathrm{mol} / \mathrm{m}^{2} / \mathrm{s}$ at $25^{\circ} \mathrm{C}$ used in the modelling of the seafloor weathering. $\mathrm{H}, \mathrm{OH}$ and $w$ stand respectively for the dissolution by $\mathrm{H}^{+}, \mathrm{OH}^{-}$and water. Note that the speciation of the water percolating the crust is calculated, so that the $\mathrm{H}^{+}$and $\mathrm{OH}^{-}$concentration of the solution can is calculated. $\mathrm{E}_{a}$ is the activation energy $(\mathrm{kJ} / \mathrm{mol}) . \mathrm{n}$ is the reaction order. The symbol $\sim$ means not applicable.

\begin{tabular}{llll}
\hline & $\mathrm{pk}_{\mathrm{H}}$ & $\mathrm{pk}_{\mathrm{OH}}$ & $\mathrm{pk}_{w}$ \\
& $\mathrm{E}_{a} \mathrm{H}$ & $\mathrm{E}_{a} \mathrm{OH}$ & $\mathrm{E}_{a} w$ \\
& $\mathrm{n}_{\mathrm{H}}$ & $\mathrm{n}_{\mathrm{OH}}$ & \\
\hline Labradorite & 8.28 & 9.7 & 11.50 \\
& 65 & 50 & 68 \\
& 0.7 & 0.3 & $\sim$ \\
\hline Diopside & 9.85 & $\sim$ & $\sim$ \\
& 42 & $\sim$ & $\sim$ \\
& 0.14 & $\sim$ & $\sim$ \\
\hline Basaltic glass & 6.70 & 9.45 & 10.35 \\
& 30 & 50 & 50 \\
& 0.5 & 0.175 & $\sim$ \\
\hline Apatite & 5.08 & $\sim$ & $\sim$ \\
& 34.7 & $\sim$ & $\sim$ \\
& 0.87 & $\sim$ & $\sim$ \\
\hline Forsterite & 6.60 & $\sim$ & $\sim$ \\
& 75 & $\sim$ & $\sim$ \\
& 0.50 & $\sim$ & $\sim$ \\
\hline
\end{tabular}

in modelling to assume present day value for unconstrained parameters in the past. Although this might not be fully justified, it can be safely assumed that this water flux has not changed by an order of magnitude compared to the present day value. Since the duration of the glacial events exceeds several million years (Bodiselitch et al., 2005), the whole oceanic content still percolates several times the oceanic crust during the snowball event, so that this process is geochemically as important in the Neoproterozoic than today.

\subsection{Ocean interactions with the oceanic crust}

\subsubsection{The seafloor weathering process}

The seafloor weathering is a carbon sink due to the dissolution of basaltic silicates (Alt and Teagle, 1999). In our model, the deep ocean is in contact with a water reservoir incorporated into the oceanic crust. Under the corrosive action of seawater, the reservoir of percolating waters is slowly depleted in carbon through low temperature dissolution of the basaltic crust. Indeed, the induced increase in alkalinity leads to the precipitation of carbonate minerals from highly saturated waters in vein inside the oceanic crust. This process removes carbon from the ocean atmosphere system at the million year timescale (Fig. 1), but does not influence the alkalinity budget since the net alkalinity flux is equal to zero. The global sink of carbon is estimated at $1.6 \times 10^{12}$ moles/yr,

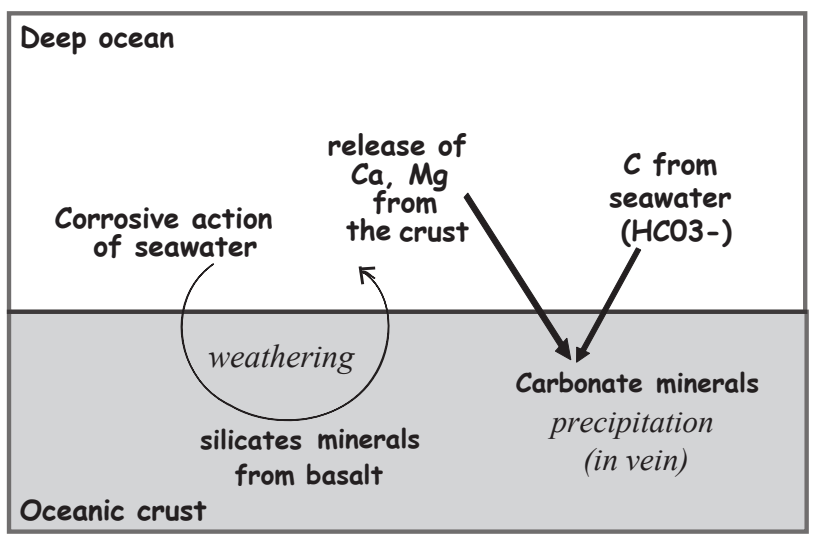

Fig. 1. Seafloor weathering is a carbon sink. Under the corrosive action of seawater, the percolating water consumes carbon by low temperature dissolution of basaltic crust. Seawater acidification enhances the corrosive ability of seawater.

at the lower end of the estimation performed by Alt and Teagle (1999) under present day conditions, but may increase with an oceanic acidification. To avoid any poorly constrained parameterization of this flux, we choose to estimate the weathering rate of the basaltic crust using laboratory kinetic laws for proton, $\mathrm{OH}^{-}$and $\mathrm{H}_{2} \mathrm{O}$ promoted dissolution.

$R_{\mathrm{bas}}=\sum_{i} k_{i} \cdot \exp \left(\frac{-E_{i}}{R \cdot T_{p}}\right) \cdot a_{i}^{n_{i}}$

This equation is a kinetic description of the dissolution rate of a silicate mineral, inferred from the transition state theory (Eyring, 1937; Godderis et al., 2006). $R_{\text {bas }}$ is the total dissolution of the basaltic rock in mol of main cation per $\mathrm{m}^{2}$ of rock per year. The sum extends up to all the dissolving species $\left(\mathrm{H}^{+}, \mathrm{OH}^{-}\right.$and $\left.\mathrm{H}_{2} \mathrm{O}\right)$, while the index i stands for the dissolving species. $E_{i}$ and $k_{i}$ are respectively the activation energy and dissolution constant for each mineral depending on the species $i$-promoted dissolution. These constants are given in Table 1. $T_{p}$ is the temperature of the percolating waters into the oceanic crust at which dissolution occurs. Here we fixed it at $313 \mathrm{~K}$ (Brady and Gislason, 1997). $a_{i}$ stands for the activity of the species $i$ that promotes dissolution, and is calculated at each timestep of the simulation through carbonate speciation while $n_{i}$ is the order of the dissolution reaction. The mineralogical composition of the oceanic crust is taken as the mineralogy of tholeitic basalt (54\% labradorite, $32 \%$ diopside, $9 \%$ basaltic glass, $4.3 \%$ apatite and $1.3 \%$ forsterite). We then multiply this rate by a constant standing for the total reactive surface of the oceanic crust. This value cannot be safely estimated so that we fix it by calibrating the flux calculated by our model under present day oceanic $\mathrm{pH}$ conditions to the $1.6 \times 10^{12}$ moles $/ \mathrm{yr} \mathrm{CO}_{2}$ consumption from Alt and Teagle (1999). 


\subsubsection{Hydrothermal fluxes at mid-ocean ridge (MOR)}

The exact balance between the net emitted $\mathrm{CO}_{2}$ flux at mid-oceanic ridges and $\mathrm{CO}_{2}$ consumption through seafloor weathering is not known, meaning that we do not really know today whether oceanic ridges act as a $\mathrm{CO}_{2}$ source or sink (Kerrick, 2001). In a conservative approximation, we assume a net MOR degassing of $\mathrm{CO}_{2}$ into the deep ocean at a constant rate of $1.6 \times 10^{12}$ moles/yr, which exactly balances the present day seafloor weathering, so that the overall interaction between the oceanic crust and the oceanic reservoir does not yield a net $\mathrm{CO}_{2}$ flux under present-day conditions.

A consumption of $\mathrm{O}_{2}$ by MOR systems through the formation of iron oxides and the precipitation of metalliferous sediments is included (Godderis, 2001). Assuming a mean water flux through on-axis MOR system of $420 \times 10^{13} \mathrm{~kg} / \mathrm{yr}$ (Elderfield and Schultz, 1996) and a complete removal of oxygen from circulating water, this sink reaches about $9 \times 10^{11}$ moles/yr under present day conditions. It is then assumed to be simply proportional to the oxygen content of the percolating seawater. Finally, phosphorus is also removed through adsorption on hydrothermal plume particles in the vicinity of MOR systems at a present day rate of $1.4 \times 10^{9}$ moles/yr (Wallmann, 2003).

All the processes involving interactions between the oceanic crust and the seawater are dependent on the seafloor spreading rate. This parameter cannot be evaluated for the Neoproterozoic. Indeed, the most accurate reconstruction of the spreading rate does not extend prior to $160 \mathrm{Ma}$ (Cogne and Humler, 2004). For the last $160 \mathrm{Myr}$ of the Earth history, the average activity of the oceanic ridge has not fluctuated by more than $20 \%$. Since the Earth's thermal history, which controls the ocean ridge activity, has remained unchanged since the Proterozoic period (Condie, 1998), we can safely assume that the seafloor spreading rate in the Neoproterozoic is similar to its present day value.

\subsection{Geochemical modelling procedure}

The geochemical model describes the time evolution of the carbon, oxygen, phosphorus and alkalinity geochemical cycles. It is a simplified and slightly modified version of the geochemical module of the GEOCLIM model (Donnadieu et al., 2004, 2006; Godderis and Joachimski, 2004) (Fig. 2). The number of oceanic reservoirs has been reduced to two: one for the surface ocean and one for the deep ocean. Two reservoirs have been added below the deep ocean reservoir: the first one accounts for the water circulating into hydrothermal system at high temperature $\left(350^{\circ} \mathrm{C}\right)$ while the second one describes the temporal evolution of the water percolating the oceanic crust along ridge flanks at low temperature $\left(40^{\circ} \mathrm{C}\right)$. Carbonate speciation is calculated within each water reservoir as a function of the modelled alkalinity, total dissolved inorganic carbon and temperature of the waters. The ocean model is capped with an atmospheric reservoir.

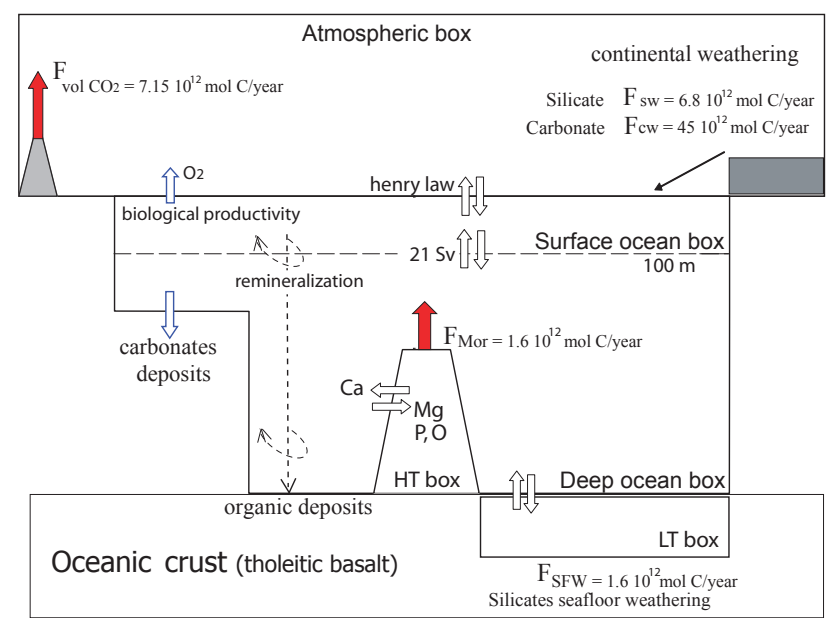

Fig. 2. Geochemical model including oxygen carbon cycle and major cations behaviour. LT box (for Low Temperature) is used to represent interactions between the deep ocean and oceanic crust occurring at low temperature $(313 \mathrm{~K})$. Innovation added in this box is the seafloor weathering process. HT box (for High Temperature) represents phenomena occurring between the deep ocean and hydrothermal vents at high temperature (cations exchanges and $\mathrm{CO}_{2}$ release). Red arrows represent carbon sources. The carbon released by aerial volcanoes $\left(7.15 \times 10^{12} \mathrm{~mol} \mathrm{C} /\right.$ year $)$ is fixed to balance the carbon consumption by the continental silicates weathering $\left(6.8 \times 10^{12} \mathrm{~mol} \mathrm{C} /\right.$ year (Gaillardet et al., 1999)) and the net bilan of the organic carbon cycle $\left(0.35 \times 10^{12} \mathrm{~mol} \mathrm{C} / \mathrm{year}\right)$. In snowball Earth conditions, we fix the ocean temperature at $2^{\circ} \mathrm{C}$ instead of $20^{\circ} \mathrm{C}$ and the oceanic overturning is reduced to $0.21 \mathrm{~Sv}$. Due to icesheet growth, the continental weathering is cut off during the glaciation. In the common case, the ice free surface is fixed at $3000 \mathrm{~km}^{2}$, the minimal value required to an efficient diffusion between the atmosphere and ocean (Le Hir et al., 2008).

To simulate the initial seawater and atmospheric composition before the global glaciation, we first run the geochemical model according to Proterozoic pre-glacial conditions until a steady-state is reached. We use a standard silicate weathering law, where $\mathrm{Ca}^{2+}$ and $\mathrm{Mg}^{2+}$ weathering rates are proportional to global runoff and depend on mean global air temperature (Oliva et al., 2004), assuming that the present silicate weathering consumes $13.2 \times 10^{12}$ moles of atmospheric carbon per year (Dessert et al., 2003; Gaillardet et al., 1999). Continental carbonate weathering is proportional to global runoff times the concentration of $\mathrm{Ca}^{2+}$ in equilibrium with calcite minerals and atmospheric $\mathrm{CO}_{2}$ at the calculated mean air temperature (Donnadieu et al., 2006). Global mean air temperature $T_{\text {air }}$ (in ${ }^{\circ} \mathrm{C}$ ) is assumed to be a function of atmospheric $\mathrm{pCO}_{2}$ (ppmv):

$T_{\text {air }}=5.1339 * \ln \left(\mathrm{pCO}_{2}\right)-24.729$

This parametric relationship was obtained by running a radiative-convective climate model (ClimT) under Neoproterozoic conditions ( 
albedo=0.3) for a variety of atmospheric $\mathrm{CO}_{2}$ levels. Finally, continental runoff is assumed to be a simple linear function of global mean air temperature (Berner and Kothavala, 2001).

Biological productivity in the surface ocean depends on (i) the incoming flux of phosphorus from the deep ocean, (ii) the weathering of continental surfaces (phosphorus flux is assumed to be proportional to runoff), and (iii) the seawater pH (Coleman, 1981). Recent studies (Canfield et al., 2007; Fike et al., 2006) demonstrate that the Neoproterozoic atmosphere remained poorly oxygenated until the second oxydation event, which occurred between 630 and $542 \mathrm{Ma}$. Consequently, the Neoproterozoic atmospheric oxygen level is thought to be around 10\% of its present value (Catling and Claire, 2005; Fike et al., 2006; Kasting, 1987). For that reason, we reduce the photosynthetic biological activity so that pre-glacial atmospheric $\mathrm{O}_{2}$ stabilizes at 0.02 bar. Carbonate deposition $F_{c d}$ occurs in the surface oceanic reservoir. Carbonate speciation is calculated at each time step, together with the saturation state of the oceanic waters $\Omega$ (Godderis and Joachimski, 2004). Carbonate deposition is then calculated as following (Opdyke and Walker, 1992):

$F_{c d}=k \cdot(\Omega-1)^{1.7}$

$\mathrm{k}$ is a calibration constant. The inception of the global glaciation is simulated through an instantaneous shut down of all continental weathering fluxes as a consequence of the rapid growth of continental ice sheets. Surface water temperature is forced to drop from $20^{\circ} \mathrm{C}$ down to $2^{\circ} \mathrm{C}$. Regarding the oceanic overturning, nobody knows about the mixing of the ocean prior to the snowball event, but there is no doubt that the thermohaline circulation should be strongly affected by the presence of a worldwide sea ice cover as the case during the Last Glacial Maximum (Lynch-Stieglitz et al., 2007). To represent a maximum oceanic circulation reduction, we force the vertical mixing between surface and deep waters to decrease from $21 \times 10^{6} \mathrm{~m}^{3} / \mathrm{s}$ (the present assumption for the oceanic circulation intensity, IPCC report) to $0.2 \times 10^{6} \mathrm{~m}^{3} / \mathrm{s}$ (or Sv), which can be considered as the minimal vertical mixing that can be reached, given that tidal forces cannot be removed and maintain a minimal mixing (Zhang et al., 2001). Then the model evolves freely. Using the lowest vertical mixing allows us to simulate the minimal impact of oceanic crust processes on the atmospheric evolution during the glacial event, since the transport of carbon and oxygen from the atmosphere down to the oceanic crust, where they are consumed, is set to its minimal value.

According to geological constrains, the maximal duration for the Marinoan glaciation event does not exceed $33 \mathrm{Myr}$ (Zhou et al., 2004; Condon et al., 2005). Here, we fix it at $30 \mathrm{Myr}$, because the deglaciation requires very high levels of $\mathrm{CO}_{2}$ to overcome the sea-ice albedo feed-back (Pierrehumbert, 2004).

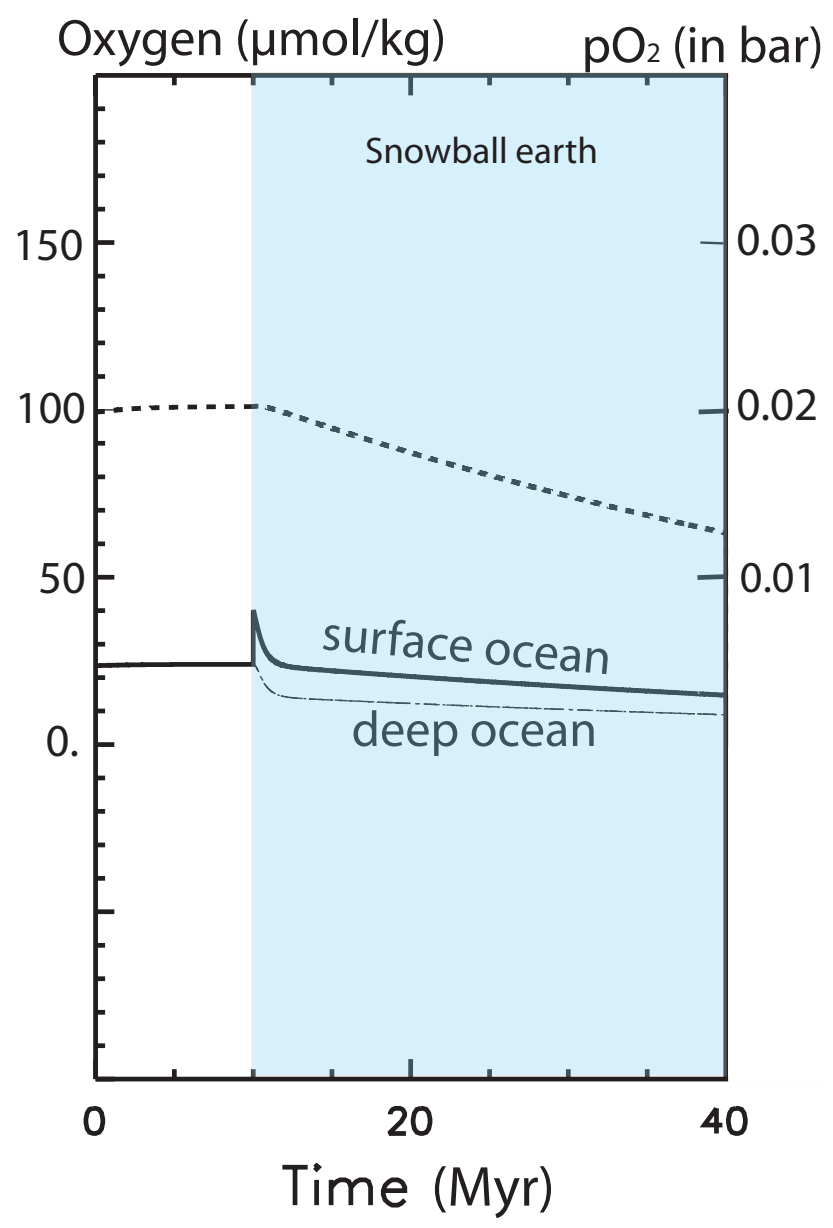

Fig. 3. Oxygen partial pressure during the glaciation with an ocean and atmosphere in steady state. The dash line represents the atmospheric $\mathrm{O}_{2}$ mixing ratio, black lines being the surface and deep ocean oxygen concentrations. The blue bland represents the glaciation duration.

\section{Impacts of oceanic crust - seawater interactions dur- ing the glaciation}

3.1 Quantification of mid oceanic ridge hydrothermal processes on seawater composition

A process closely tied to submarine hydrothermal activity is the oxygen consumption by oxide formation. Prior to the onset of the snowball glaciation, and during the early phase of this glaciation, the deep ocean remains in the dysoxic domain at $0.025 \mathrm{mmol} / \mathrm{kg}$, at a value close to the surface ocean value and constrained by the low atmospheric level (Fig. 3). Indeed, we reduced the biological productivity in the surface ocean to simulate a low atmospheric $\mathrm{O}_{2}$ level prior to the glacial event. As a result, the reduced carbon flux down to the deep ocean is decreased, reducing the $\mathrm{O}_{2}$ consumption required by its remineralization, resulting in a weak vertical $\mathrm{O}_{2}$ gradient. During the glaciation, the production of $\mathrm{O}_{2}$ by 

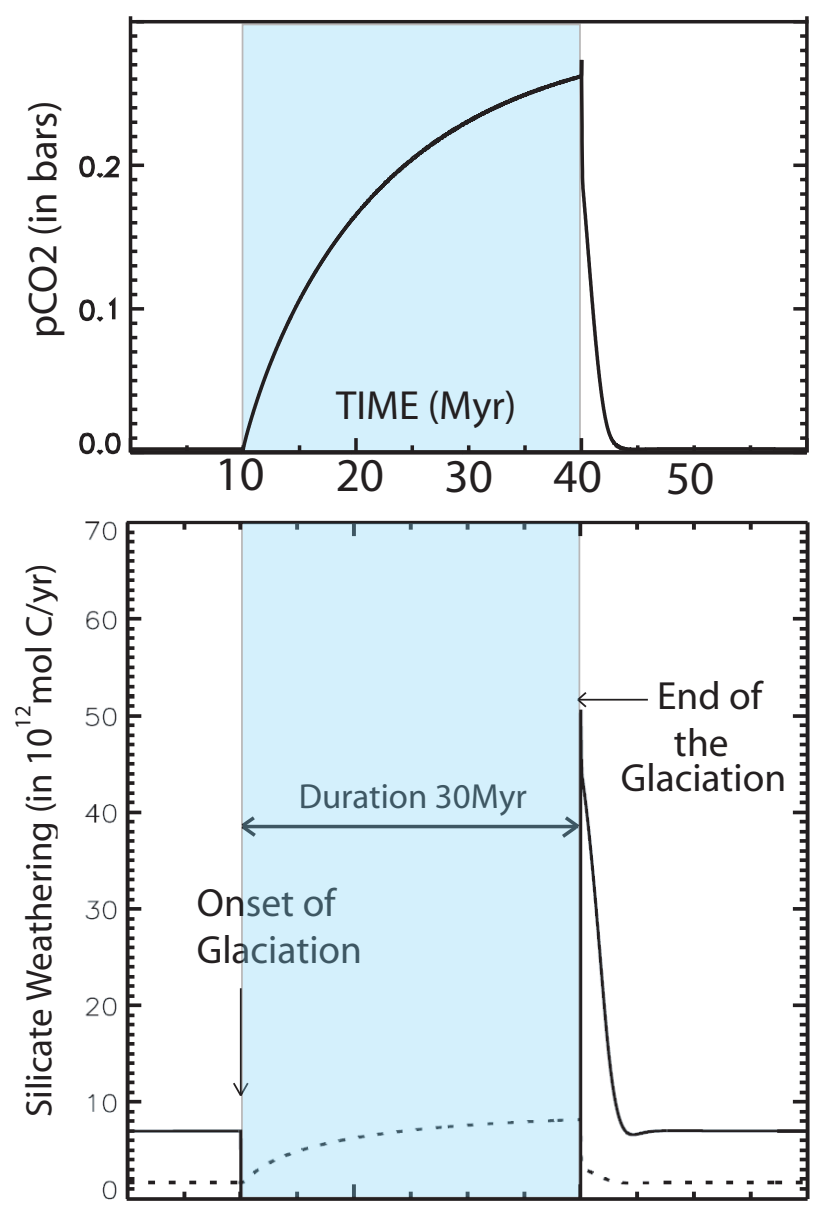

Fig. 4. The $\mathrm{CO}_{2}$ evolution as a function of the snowball Earth duration. Silicate weathering fluxes (in $10^{12} \mathrm{~mol} / \mathrm{yr}$ ) on continents (black line) and seafloor (dash line). The blue bland represents the glaciation duration.

photosynthesis and subsequent organic carbon burial rapidly goes down with the oceanic productivity. Indeed, phosphorus is rapidly consumed by hydrothermal processes due to its short residence time $\left(10^{5} \mathrm{yrs}\right)$, and the ocean rapidly lacks nutrients (within 1 million years after the beginning of the glaciation). Furthermore, the drastic reduction in vertical mixing leads to the lowering of the oxygenation of deep waters. As a consequence the oxygen consumption by hydrothermal activity overcomes the oxygen input at depth and enhances the anoxia of the deep ocean. In permanent contact with the atmosphere, the oxygen concentration of the surface ocean remains quasi-constant along the glacial interval, being only affected by the long term global exospheric $\mathrm{O}_{2}$ reduction due to consumption in hydrothermal systems. A short oxygenation event is calculated at the inception of the glaciation. Due to the prescribed oceanic temperature decrease from $20^{\circ} \mathrm{C}$ down to $2^{\circ} \mathrm{C}$, the oxygen solubility enhancement results in a rapid and short lived oxygen dissolution into the ocean.
The constant dissolution of atmospheric oxygen into the ocean through patches of open waters and its continuous consumption at mid oceanic ridges leads to a slow decrease in the atmospheric oxygen level. Within $30 \mathrm{Myr}$, the atmospheric $\mathrm{pO}_{2}$ decreases by $30 \%$, which is not enough to generate a fully anoxic surface ocean. After $30 \mathrm{Myr}$ of simulation, the weakness of the vertical oceanic mixing allows the deep ocean to become depleted in $\mathrm{O}_{2}(\sim 9 \mu \mathrm{mol} / \mathrm{kg})$. If the vertical mixing was divided by 10 or 50 instead of $100, \mathrm{O}_{2}$ concentration would respectively tends towards 11 and $10 \mu \mathrm{mol} / \mathrm{kg}$. Therefore during the glaciation, the ocean tends to be "stratified" with a poorly oxygenated deep ocean $(\sim 10 \mu \mathrm{mol} / \mathrm{kg}$ dissolved $\left.\mathrm{O}_{2}\right)$ and dysoxic surface ocean $(\sim 20 \mu \mathrm{mol} / \mathrm{kg})$. This result can explain iron formation occurrences associated with glacial deposits (Hoffman and Schrag, 2002; Young, 1992). Indeed the precipitation of iron formation (BIF) requires three conditions to be verified: (1) deep ocean anoxia, (2) low sulphur availability, and (3) surface-water oxygenated. Here, our model simulated a "quasi" anoxic deep ocean with a dysoxic surface ocean, thus facilitating the precipitation of BIFs. Regarding sulphur availability, we can only speculate that the absence of weathering implies a shut down of riverine sulphate input, since no sulphur cycle is implemented. Hence, we assume that the iron formation reappearance during the glaciation remains plausible where upwelling currents carry reduced iron from the deep ocean, explaining their limited extension.

3.2 Carbon cycle evolution, seafloor weathering and carbonate dissolution

Before the glacial event, calculated seafloor weathering consumes $1.6 \times 10^{12}$ carbon mol/year, the main carbon consumption being located on the continents through aerial silicate weathering (Fig. 4). During the glaciation, the growth of large ice sheets led to the collapse of the $\mathrm{CO}_{2}$ consumption through continental weathering and biological carbon pumping, and consequently to the atmospheric $\mathrm{CO}_{2}$ built up (Fig. 4). If the $\mathrm{CO}_{2}$ is allowed to dissolve within the ocean during the building up of high atmospheric carbon levels, seawater pH (Fig. 5) and $\Omega$ should drastically decrease, and promote both carbonates (Hoffman and Schrag, 2002) and oceanic basaltic crust dissolutions, both processes counteracting the $\mathrm{pH}$ decrease. However the absence of pelagic calcifying organisms before the Mesozoic (Bown, 2004; Kuznetsova, 2003) excludes the possibility to accumulate deep sea carbonates. The other source of alkalinity might have been the dissolution of carbonate precipitated on the continental platform prior to the glaciation. However the sea level drop induced by the global glaciation has certainly strongly reduced the availability of this carbonate reservoir for dissolution. Nevertheless, since carbonates begin to dissolve when $\Omega$ decreases below 1, it is worthy to estimate the maximal amount of carbonates that can be dissolved during the glacial event itself. 


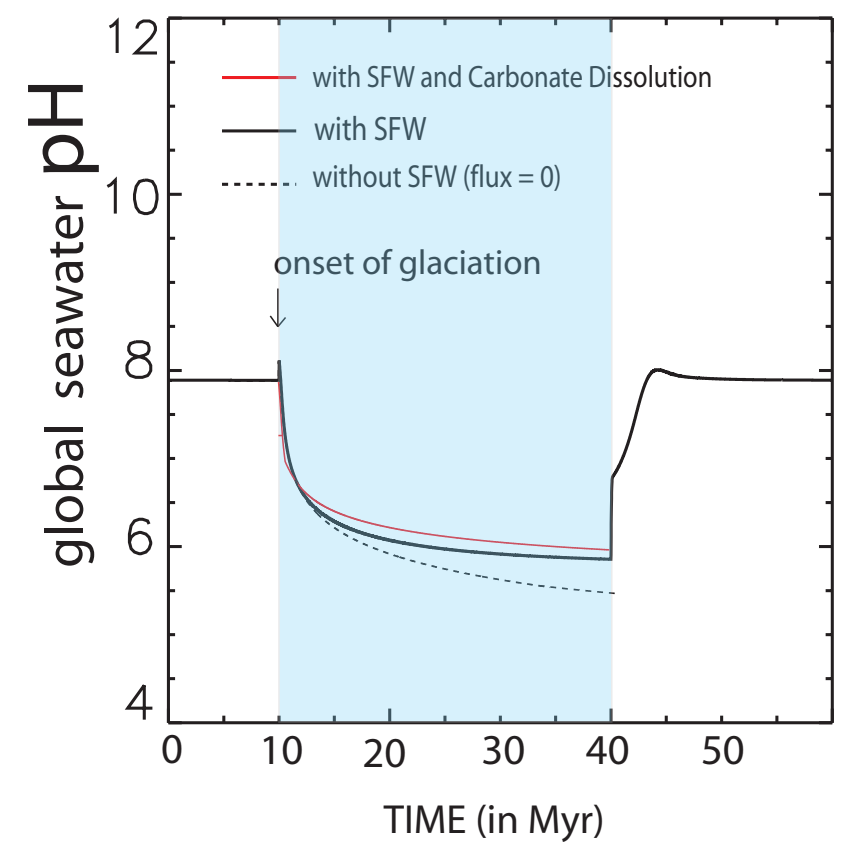

Fig. 5. $\mathrm{pH}$ evolution of the ocean during the glaciation. Snowball Earth begins after $10 \mathrm{Myr}$ and lasts $30 \mathrm{Myr}$. All runs show, that during a snowball event, the seawater $\mathrm{pH}$ tends towards acidic values. Consequently, the seafloor weathering (SFW) increases its $\mathrm{CO}_{2}$ consumption. By this way the $\mathrm{pH}$ is stabilized. The blue bland represents the glaciation duration.

Carbonate dissolution is a function of the saturation state of the seawater with respect to carbonate minerals $\Omega$. Once saturation is reached, dissolution stops. Dissolution $F_{\text {diss }}$ can be described by the following equation as long as $\Omega$ stays below 1:

$F_{\text {diss }}=k_{\text {diss }} \cdot(1-\Omega)^{1.7}$

where $k_{\text {diss }}$ is a constant representing the dissolution flux of carbonate in $\mathrm{mol} / \mathrm{yr}$ when undersaturation is complete $(\Omega=0)$. The value of the exponent is not well constrained, and we choose to keep it at the same value as in Eq. (3). The amount of carbonates that can be dissolved is thus strongly controlled by the saturation state of the ocean. Just after the onset of the global glaciation, $\Omega$ starts to decrease, in response to the shut down of the continental weathering and the early stages of the $\mathrm{CO}_{2}$ accumulation into the exospheric system. Once $\Omega$ is below 1 , dissolution of carbonate minerals begins, releasing two equivalent of alkalinity and one mole of carbon per mole of carbonate mineral. This dissolution counteracts further decrease in $\Omega$, but also fixes the temporal evolution of $F_{\text {diss }}$. The $k_{\text {diss }}$ constant can be seen as a restoring force counteracting any $\Omega$ decrease: the bigger it is, the stronger the buffering effect will be, and the closer to saturation will stay the seawater. We calculated that the minimum value of $k_{\text {diss }}$ required to stabilize seawater at $\Omega=1$ is equal to $10^{15} \mathrm{~mol} /$ year. Assuming this maximum buffering effect, we found that during

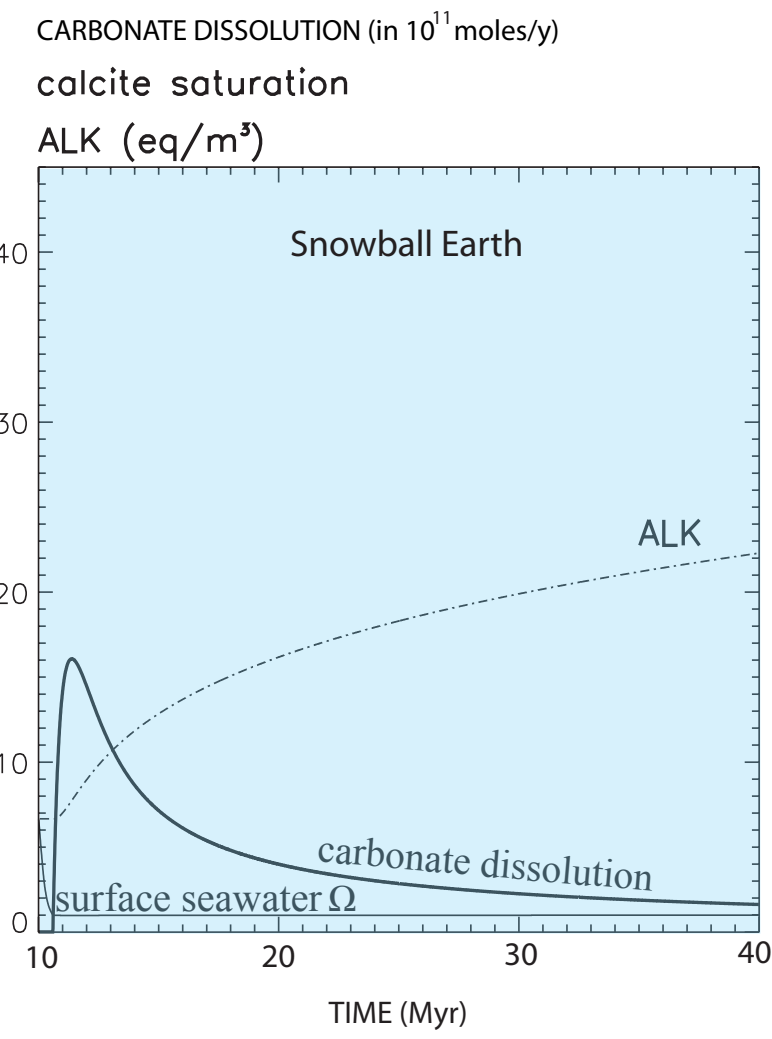

Fig. 6. Evolution of the surface seawater omega and alkalinity during a snowball Earth (duration $30 \mathrm{Myr}$ ). The carbonate dissolution is enough efficient to stabilize the omega at 1 . The blue bland represents the glaciation duration.

the first 10 million years of the glacial event, $\sim 15 \times 10^{20} \mathrm{~g}$ of seafloor carbonate are dissolved (Fig. 6). Assuming area of carbonate accumulation on shelves of $15 \times 10^{6} \mathrm{~km}^{2}$ prior to the snowball, which is a kind of a maximum value, corresponding to the Upper Cretaceous environment (Walker, 2002), this carbonate mass would be $35 \mathrm{~m}$ thick. Such mass of carbonate seems to overcome the low availability of shelf carbonates during global glaciations (because of sea level drop). Another carbonate source comes from debris carried by the wet based inlandsis (Donnadieu et al., 2003). This flux is not constrained, but a continental carbonate flux has definitively occurred during the glaciation. Based on the above estimation of the carbonate mass required to keep saturation state of the ocean around 1, the continental carbonate flux should represent a layer reaching $\sim 3.5 \mathrm{~m}$ of thickness over all the continents, during the first 10 million years of the glaciation. In consequence, according to our simulations, the limiting factor to maintain a saturated ocean during the glacial event appears to be the carbonates mass available in oceans and/or on continents. Our results suggest that the buffering effect of carbonate dissolution in the ocean was limited to the first stages of a snowball glaciation. 


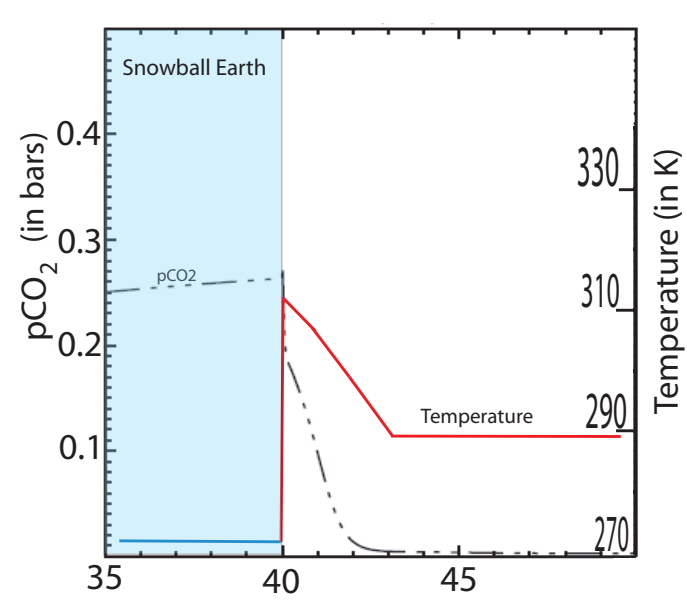

TIME (in Myr)

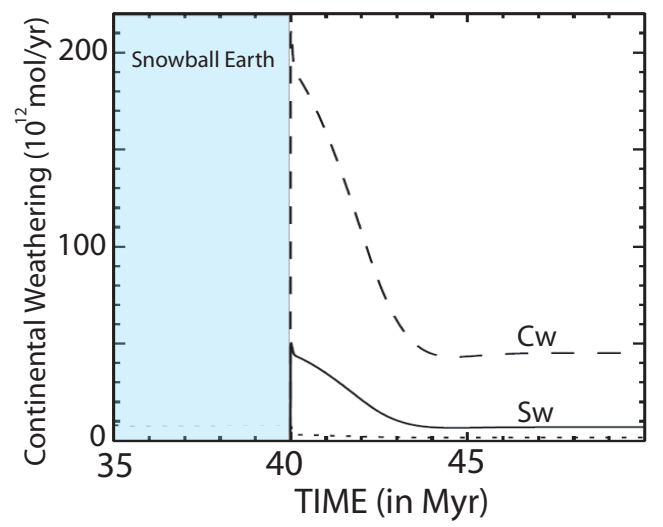

\begin{tabular}{lllllll}
\hline $\begin{array}{l}\text { Continental } \\
\text { weathering }\end{array}$ & $\begin{array}{l}\mathrm{t}_{0}+10 \mathrm{kyr} \\
\text { Deglaciation }\end{array}$ & $\mathrm{t}_{0}+100 \mathrm{kyr}$ & $\mathrm{t}_{0}+200 \mathrm{kyr}$ & $\mathrm{t}_{0}+400 \mathrm{kyr}$ & $\mathrm{t}_{0}+1 \mathrm{Ma}$ & $\mathrm{t}_{0}+2 \mathrm{Ma}$ \\
\hline $\begin{array}{l}\text { Carbonate } \\
\left.\text { (in } 10^{15} \mathrm{~g} / \mathrm{yr}\right)\end{array}$ & 21 & 19.2 & 18.8 & 18.5 & 15.9 & 10.7 \\
$\begin{array}{l}\text { Silicate } \\
\left.\text { (in } 10^{15} \mathrm{~g} / \mathrm{yr}\right)\end{array}$ & 5 & 4.4 & 4.3 & 4.2 & 3.47 & 2.1 \\
Higgins and Schrag (Higgins and Schrag, 2003) - total weathering used 17, 10 or 5 (in $10^{15} \mathrm{~g} / \mathrm{yr}$ ).
\end{tabular}

Fig. 7. Temperature, $\mathrm{pCO}_{2}$ and weathering flux in the aftermath of the glaciation. The blue bland represents the glaciation duration. $\mathrm{Cw}$ is for Carbonate Weathering rate (dash line) and $\mathrm{Sw}$ for Silicate Weathering (black line).

Regarding the $\mathrm{pH}$ trend, even if we impose unlimited carbonate dissolution during the glaciation, it does not balance the $\mathrm{pH}$ decrease (Fig. 5, red curve) linked to the dissolution of the growing atmospheric $\mathrm{CO}_{2}$ stock. The global ocean is saturated $(\Omega=1)$, but largely acidic a few million years after the glaciation onset ( $\mathrm{pH} \sim 6.2$ ). Indeed, the massive release of $\mathrm{Ca}^{2+}$ by the unrestricted carbonate dissolution reduces the $\mathrm{CO}_{3}^{2-}$ level required to maintain $\Omega=1$ (Fig. 6).

Therefore we suggest that carbonate dissolution cannot counteract the deep acidification of seawater during a snowball event. Hence, the seawater acidification enhances the consumption of dissolved carbon through low temperature alteration of the oceanic basaltic crust. The $\mathrm{CO}_{2}$ consumption through seafloor basaltic weathering rises until the ocean is sufficiently acidified (Fig. 5) so that seafloor weathering balance the prescribed total solid Earth outgassing $\left(8.65 \times 10^{12} \mathrm{~mol} / \mathrm{year}\right)$ (Fig. 4). This oceanic crust-ocean interaction partly buffers the seawater acidification, maintaining $\mathrm{pH}$ around 6 , while it goes below this threshold in the absence of seafloor weathering (Fig. 5).

However, the efficiency of seafloor weathering depends not only on the kinetic dissolution rate of the crust and on the seawater composition, but also on the vertical mixing of the ocean. Indeed, cutting down completely the vertical mixing during the snowball will leave the seafloor weathering without any impact on the carbon content of the atmosphere, because carbon accumulating in the atmosphere cannot be brought in contact with the oceanic crust. Considering that tidal forces weakly mix yet the ocean (Garrett, 2003) and that a fully stratified ocean cannot be physically maintained during a long period of time (Zhang et al., 2001), a weak overturning should have certainly existed even below a largely ice-covered ocean. Here, reducing by 2 orders of magnitude the present day vertical mixing, the seafloor weathering remains efficient which supports our scenario of the seawater evolution. (Factors altering the seafloor weathering are fully discussed in Le Hir et al. (2008)).

\section{Seawater properties aftermath to the glaciation}

\subsection{Post glacial warming duration and seawater hypoxia}

The cap carbonates overlapping glacial diamictites shows a "knife-edge" contact suggesting no significant hiatus. This abrupt juxtaposition implies an instantaneous shift from icehouse to extreme green-house conditions (Hoffman et al., 1998). Geological and modelling studies suggest that this transition could have lasted between 100 years (Halverson et al., 2004) and $10 \mathrm{kyr}$ (Higgins and Schrag, 2003). The melting of the snowball Earth is the result of the mega greenhouse effect induced by a high atmospheric $\mathrm{CO}_{2}$ mixing ratio. Even if uncertainties remain on the $\mathrm{pCO}_{2}$ required to overcome the high albedo of a snowball Earth, a modelling study (Pierrehumbert, 2005) demonstrates that this value overcomes 0.2 bar and might be equal to 0.29 bar.

Our model prescribes the termination of the glaciation after $30 \mathrm{Myr}$, which leads to a final $\mathrm{pCO}_{2}$ level reaching $0.26 \mathrm{bar}$, a value close to the melting threshold estimate. Once the melting of the ice completed, such a high $\mathrm{pCO}_{2}$ value induces a large warming effect (Fig. 7). The surface temperature shifts from $275 \mathrm{~K}$ (maintained constant during the glacial event) to $\sim 310 \mathrm{~K}$ in a few $10^{4}$ years. This sudden and extreme warming further enhances the dysoxia in seawater, since solubility of $\mathrm{O}_{2}$ coevally decreases, and oxygen concentration in surface waters falls from 24.4 down to $11.4 \mu \mathrm{mol} / \mathrm{kg}$.

With ice meltdown, the continental surface reappears. Warm temperatures and large runoff calculated in the 
aftermath of the glaciation result in a strong continental weathering. $\mathrm{CO}_{2}$ consumption by continental silicate rock weathering rises up by a factor of 7 compared to present day values (Fig. 7). This increase, combined with the restart of the carbonate burial engine, results in a quick decline of $\mathrm{CO}_{2}$ and a return toward initial conditions in $\sim 3 \mathrm{Myr}$, a duration longer than the $200 \mathrm{kyr}$ previously estimated (Higgins and Schrag, 2003).

4.2 The termination of an acidic ocean and the deposition of the cap carbonates: origin and timing

Since carbonates are highly soluble in an acidic ocean, the carbonate reappearance is generally interpreted as the termination of the acidic ocean prevailing during the glaciation. Carbonates immediately capping the glacial deposits are supposed to be formed by the rapid continental carbonate weathering in the direct aftermath of the snowball, and are usually interpreted as a transgressive unit precipitated during the sea level rise. Indeed, field observations (Hoffman and Schrag, 2002, and references therein) show that Marinoan cap carbonates are transgressive. Nevertheless, it should be noted that most Sturtian cap carbonates are formed after the postglacial transgression (Hoffman and Schrag, 2002; Shield, 2005). A classic estimation for the sea-level rise, based on Quaternary ice-sheets meltdown analog, is $10 \mathrm{kyr}$. However, estimation of the amount ice stored on the continent during the snowball event from geological (Hoffman et al., 2007) and numerical estimates (Donnadieu et al., 2003) suggests a volume of $\sim 200$ millions of $\mathrm{km}^{3}$, which is four time the ice volume melted between the Last Glacial maximum and the interglacial. Hence, inferring Quaternary deglaciation duration within the snowball context is difficult, and it is reasonable to ask questions whether this analogy is safe or not.

Under direct post glacial conditions (acid rains induced by 0.26 bars of $\mathrm{CO}_{2}$, intense runoff and warm temperatures), our thermodynamic model for carbonate dissolution predicts a carbonate weathering rate peaking at $\sim 2.1 \times 10^{14} \mathrm{~mol}$ of $\mathrm{Ca}^{2+} / \mathrm{yr}$ (4 times the pre-glacial value, see Fig. 7), a flux large enough to accumulate a carbonate bank of $8.5 \mathrm{~m}$ on the whole continental shelf area (assuming an shelf extent of $15.10^{6} \mathrm{~km}^{2}$, once again the maximal Phanerozoic extent) in only $10 \mathrm{kyr}$. Therefore, the mass of carbonate coming from the post-glacial carbonate weathering is largely enough to lead to the precipitation of the cap carbonates.

However additional conditions are required for carbonates to precipitate: seawater must return to saturation with respect to carbonate minerals. After the melting of the ice sheets, and since the carbonate saturation cannot be maintained during the glacial event, the post glacial ocean display a $\mathrm{pH}$ of 6 , and a saturation ratio $\Omega$ virtually equal to 0 . Even if large amounts of $\mathrm{Ca}^{2+}$ and $\mathrm{HCO}_{3}^{-}$are released from the continents into the ocean, it takes time to balance the initial acidity, and restore saturated conditions with respect to calcite mineral. As shown in Fig. 8, the ocean needs 20 kyr to restore satura- tion $(\Omega>1)$ through the high flux of alkalinity coming from continental weathering. In our model, the precipitation of cap carbonates occurs, not immediately but almost at the geological timescale, $20 \mathrm{kyr}$ after the deglaciation. We thus suggest that cap carbonates are not accumulated in the early phase of the melting. Sedimentation during this time-span might have been driven by intense mechanical erosion of continents, and results in the accumulation of siliclastic deposits, which are thus the terminal diamictites. The shift from a global glaciation to a supergreenhouse climate was thus not recorded by the restart of carbonate sedimentation, but $20 \mathrm{kyr}$ above this limit. This means that the calculated carbonate sedimentation hiatus does not necessarily correspond to a total sedimentation hiatus.

Regarding the sedimentological context of the cap carbonates, the duration of the sea level rise appears important. Indeed, if the sea level rise occurs in more than $20 \mathrm{kyr}$, then our modelled cap carbonates precipitate in a trangressive context, in agreement with the Marinoan data (Hoffman and Schrag, 2002). Conversely, duration shorter than $20 \mathrm{kyr}$ would induce non transgressive cap carbonates. It should be also noted that $20 \mathrm{kyr}$ to restore the carbonate precipitation is the minimal duration. Indeed, if the required $\Omega$ to obtain an ubiquitous carbonate precipitation is higher than 1 , for instance $\Omega=10$ (Ridgwell and Zeebe, 2005) the hiatus will exceed $20 \mathrm{kyr}$ (Fig. 8). The exact threshold allowing carbonate precipitation is not well-known, especially because the first meter of the cap carbonates sequence is formed by dolomite minerals, not calcite. Up to now, nobody knows how the post glacial dolomites are formed. Hence, the saturation state for dolomite being very unconstrained, the timing for the cap carbonates precipitation remains only indicative.

\subsection{Isotopic records of $\delta^{13} \mathrm{C}$ in cap carbonates}

Cap carbonates are a key element of the snowball theory and many discussions were focused on their origin, and the significance of seawater $\delta^{13} \mathrm{C}$ they recorded. A fine description of the cap carbonate succession reveals two units (Hoffman and Schrag, 2002): a basal unit of cap dolostone with an initial $\delta^{13} \mathrm{C}$ of -2 and a subsequent unit of limestone with a $\delta^{13} \mathrm{C}$ tending towards 0 (Higgins and Schrag, 2003). The dolostone-limestone transition is characterized by a $\delta^{13} \mathrm{C}$ of -4 (Higgins and Schrag, 2003; Hoffman and Schrag, 2002). A previous geochemical model study by Higgins and Schrag (2003) focused on post glacial isotopic records, suggesting that the basis of the cap carbonate deposition is driven by alkalinity input from carbonate weathering. They also assumed that the negative $\delta^{13} \mathrm{C}_{\text {carb }}$ trend, observed in dolostones, was induced by surface temperature and the saturation state of the ocean. The main weakness of this study is the lack for constraint on the snowball ocean, since all calculations start at the melting of the ice. The results are thus highly dependent on initial conditions for the $\delta^{13} \mathrm{C}$ of the ocean-atmosphere system, and the saturated state of the 

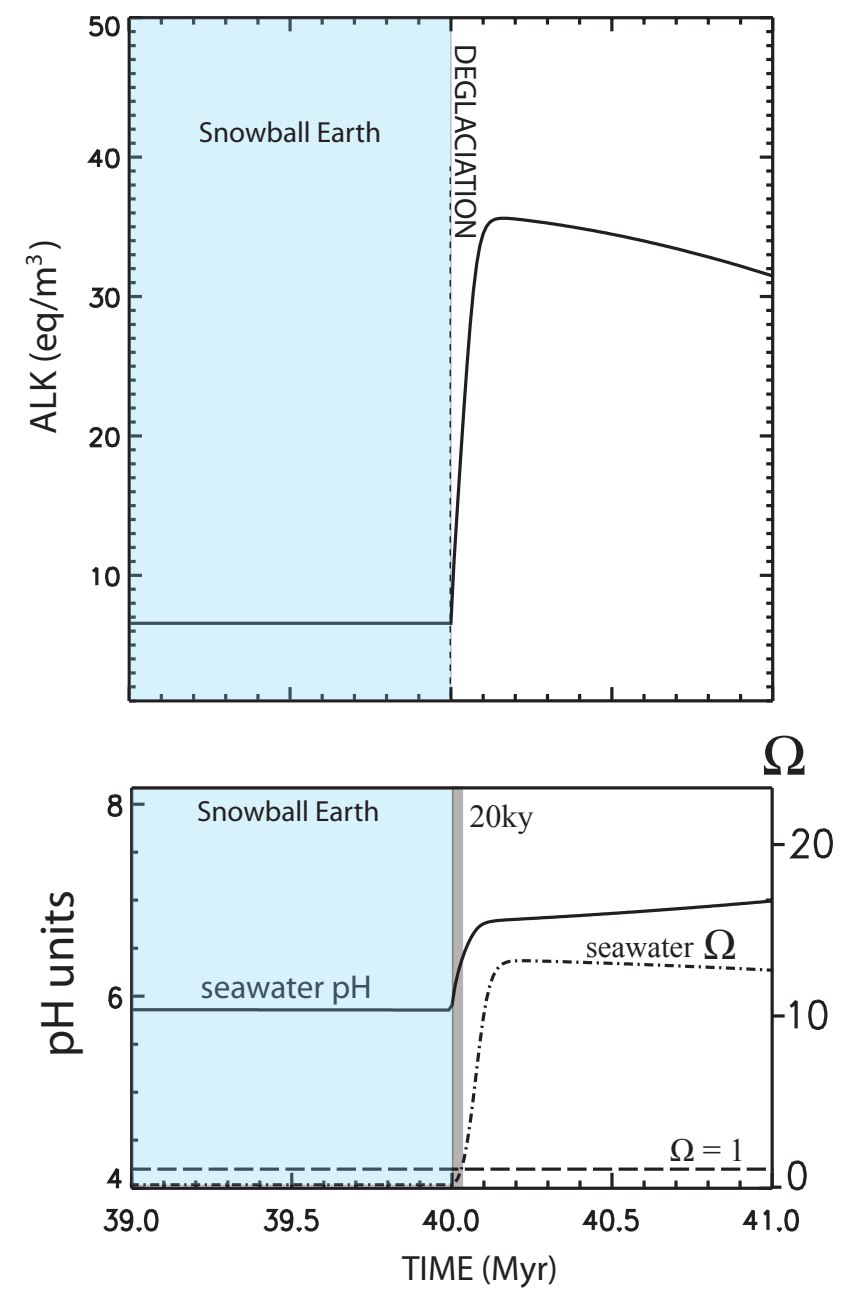

Fig. 8. Seawater saturation the termination of the glaciation (occurring at $40 \mathrm{Myr})$. The grey band shows the minimum time (20 kyrs) to reach the saturation after the termination of the glaciation. The blue bland represents the glaciation duration.

ocean just after the melting of the snowball. Here we calculate the time evolution of the ocean during the snowball event (including $\delta^{13} \mathrm{C}$ and saturation state), thus fully relaxing the initial pre-glacial conditions, prior to explore the direct post glacial ocean.

During the snowball glaciation, the building of a high DIC reservoir in the ocean while alkalinity remains fixed as a result of continental weathering collapse induces a shift of the main dissolved carbon species from $\mathrm{HCO}_{3}^{-}$to $\mathrm{H}_{2} \mathrm{CO}_{3}$. The collapse of biological productivity slowly decreases the $\delta^{13} \mathrm{C}$ of DIC to mantle values ( $-4 \%$ ) (Fig. 9a). Because $\mathrm{H}_{2} \mathrm{CO}_{3}$ is depleted in ${ }^{13} \mathrm{C}, \mathrm{HCO}_{3}^{-}$and $\mathrm{CO}_{3}^{2-}$ display rather high $\delta^{13} \mathrm{C}$ during the glacial phase in order to maintain the ${ }^{13} \mathrm{C}$ balance (see the green curve on Fig. 9a). It is interesting to mention that DIC $\delta^{13} \mathrm{C}$ goes below the mantle value during the glaciation to -6 when accounting for the sea floor weathering (red line on Fig. 9a) whereas it reaches only -3 without sea floor

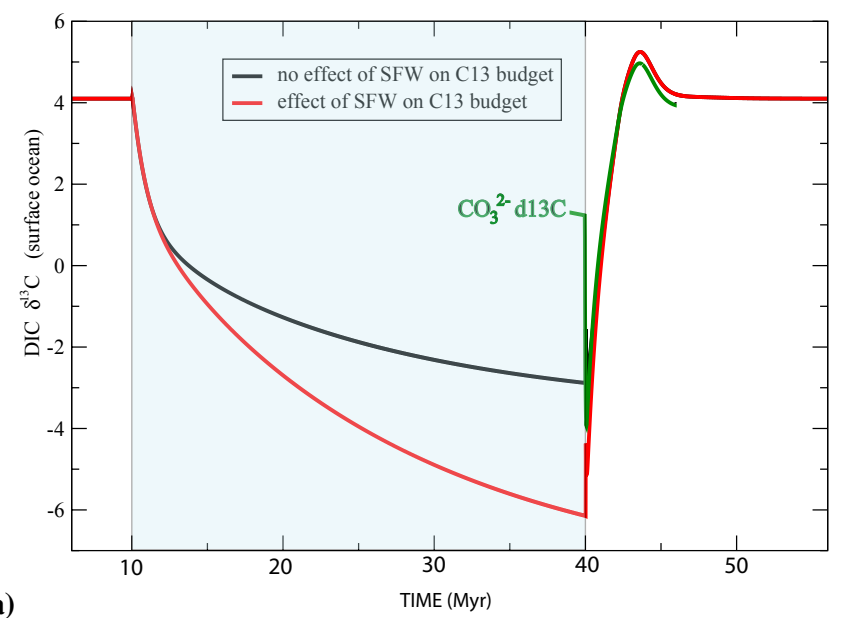

(a)

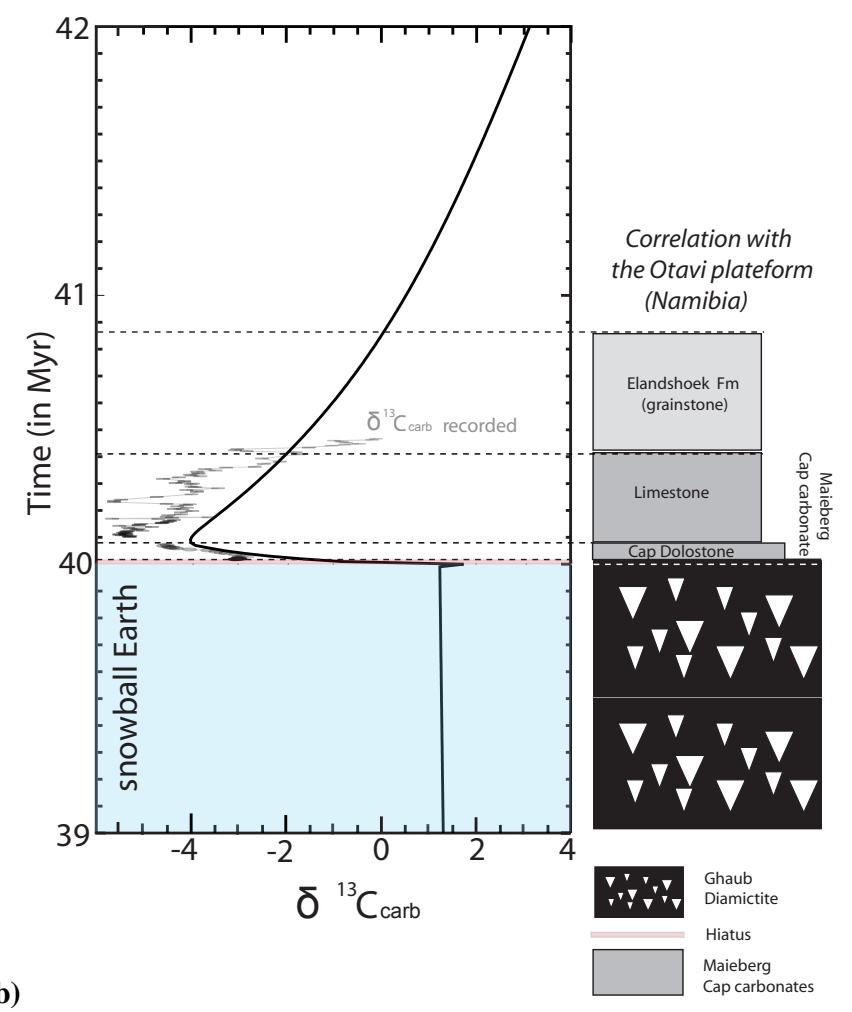

Fig. 9. (a) Modeled $\delta^{13} \mathrm{C}$ profile during and aftermath the global glaciation. The blue bland represents the glaciation duration. (b) The comparison between modelled isotopic variations and isotopic records in Otavi Plateform carbonates (Namibia). The blue bland represents the glaciation duration.

weathering (black line Fig. 9a). This result is linked to the carbon sink that consumes carbon at the $\delta^{13} \mathrm{C}$ value of $\mathrm{CO}_{3}^{2-}$, thus inducing a fractionation and further removing ${ }^{13} \mathrm{C}$ from the seawater (Fig. 9a). As a consequence, the $\delta^{13} \mathrm{C}$ of $\mathrm{CO}_{3}^{2-}$ at the end of the snowball Earth is at +1.2 (Fig. 9b). Then the restart of continental weathering, the deacidification of 
seawater and the rise in temperature decrease this value down to -4 within $10^{5}$ years after the melting, followed by a slow recovery to pre-glacial values within 2 to 3 million of years.

The comparison between our result and isotopic records in cap carbonates suggests that the most negative peak in $\delta^{13} \mathrm{C}$ (i.e. -4) appears $80 \mathrm{kyr}$ after the onset of the deglaciation and is coeval with the transition from cap dolostone to limestone (Fig. 9b). Since the ocean was undersaturated during the first $20 \mathrm{kyr}$ after the deglaciation, it explains the absence of recorded positive $\delta^{13} \mathrm{C}_{\text {carb }}$ values just after the glaciation termination. Indeed, the first carbonate being deposited displays a calculated $\delta^{13} \mathrm{C}$ of -2 , in good agreement with the $\delta^{13} \mathrm{C}$ profile measured across the cap carbonates.

These results are qualitatively in agreement with previous calculations (Higgins and Schrag, 2003), but the timing is drastically different. In the Higgins and Schrag study, the authors assumed that this high level of $\mathrm{CO}_{2}$ is consumed in only $\sim 200 \mathrm{kyr}$. In the present simulations, it takes respectively 3 and 2 million years to consume the 0.26 and 0.12 bars of post-glacial $\mathrm{CO}_{2}$ through silicate continental weathering (Fig. 7). Based on the ${ }^{13} \mathrm{C}$ output displaying the return to the pre-glacial of +4 only after $2 \mathrm{Myr}$ (Fig. 9b), correlations with Ghaub Formation (Hoffman et al., 1998) suggest that the timing of cap carbonate deposition may be longer than initially suggested, up to $400 \mathrm{kyr}$ (Fig. 9b). This longer time-span for deposition is in agreement with the existence of multiple magnetic reversals inside the first $20 \mathrm{~m}$ of the Puga cap carbonate sequence in Brazil (Trindade et al., 2003).

\section{Discussion}

Here we have quantified environmental stresses during and in the aftermath of a snowball Earth. Our geochemical model shows that the oceanic environment was submitted to large and long term perturbations during the glaciation. After $30 \mathrm{Myr}$ of glaciation, the ocean was cold, acidic, undersaturated with respect to carbonate minerals, dysoxic above $100 \mathrm{~m}$, and almost anoxic at depth. Maintenance of life under this environment is difficult to assess.

The closest analog to Neoproterozoic snowball Earth environment may be landfast sea ice in the modern-day polar regions. Under a sea ice (McKay, 2000), perennial microbial mats survive in association with a large biota, polar regions being sites wherein a large diversity of organisms is maintained (protists, metozoa or bacteria). Cyanobacteria communities existing in a cold environment show an extreme tolerance to low temperature (Vincent and Howard-Williams, 2000) even if their growth appears limited (Price and Sowers, 2004). Moreover as large populations of microscopic organisms can fit in a small surface wherein the light remains available, they can preserve a relative diversity even if small oasis remain (Knoll, 2003). Therefore cold temperatures and sea-ice extension were probably not the worse environmental forcing, but the snowball ocean was also acidic. Since a significant part of Neoproterozoic primary producers were cyanobacteria, we focused on their photosynthetic efficiency as a function of acidification (Coleman, 1981). Based on biotic response of present day living cyanobacteria, the primary production is reduced as $\mathrm{pH}$ goes down (Fig. 10), and fully collapses around $\mathrm{pH} 5$, thus below the minimum seawater $\mathrm{pH}$ calculated during the glaciation. Moreover the slow drop of the photosynthesis activity as a function of declining $\mathrm{pH}$ is not in agreement with an abrupt extinction. The snowball ocean was possibly characterized by weak primary production, limited by low temperature and low $\mathrm{pH}$, while the dysoxic conditions prevailing in the surface waters were not largely different compared to the oxic state of the photic zone prior to the snowball.

Our results suggest that the most important environmental pressure occurred during the deglaciation, and not during the snowball event itself. At the termination of the glaciation the ocean becomes warm, hypoxic and reaches a neutral $\mathrm{pH}$ in $20 \mathrm{ky}$, an extremely short time span, in response to the restart of the continental inputs through weathering.

\section{Uncertainties and limitations}

Most of our results partly depend on the assumption that the ocean and atmosphere are in contact through cracks in the sea ice, and that gas exchange is fast enough so that the ocean and atmosphere are close to equilibrium with respect to each other. Sea-ice thickness estimates for a globally icecovered Earth largely depend on the model of ice dynamic used (Goodman and Pierrehumbert, 2003; Pollard and Kasting, 2005; Warren et al., 2002). The maximum thickness has been estimated around one kilometer in the tropics and several kilometers in middle latitudes. Such a thick sea-ice may limit the crack propagation, and thus reduce the gas exchanges between the atmosphere and ocean. However, the existence of emerged hydrothermal area through melting of the sea ice may still allow gas exchanges. Furthermore, Le Hir et al. (2008) have shown that open water areas around several $10^{3} \mathrm{~km}^{2}$ are large enough to maintain an efficient gas exchange between the ocean and the atmosphere. Nevertheless, an isolated scenario cannot be a priori rejected, and we performed a simulation assuming no exchanges between the atmosphere and the ocean.

In an isolated ocean, the oxygen level drops very quickly in the surface and deep waters. The hydrothermal sink entirely consumes the oxygen available in the ocean within $1 \mathrm{Myr}$. Furthermore, the accumulation of carbon in the ocean is now limited to the degassing at mid-oceanic ridges, and the seafloor weathering rapidly buffer the $\mathrm{pH}$ decrease, keeping it around 8 (Fig. 11). However, contrary to an "open" scenario, this result is critically dependent on the relative importance of MOR degassing and consumption of carbon through seafloor weathering (assumed to be balanced at $1.6 \times 10^{12} \mathrm{moles} / \mathrm{yr}$ today) (Alt and Teagle, 1999). Since no 


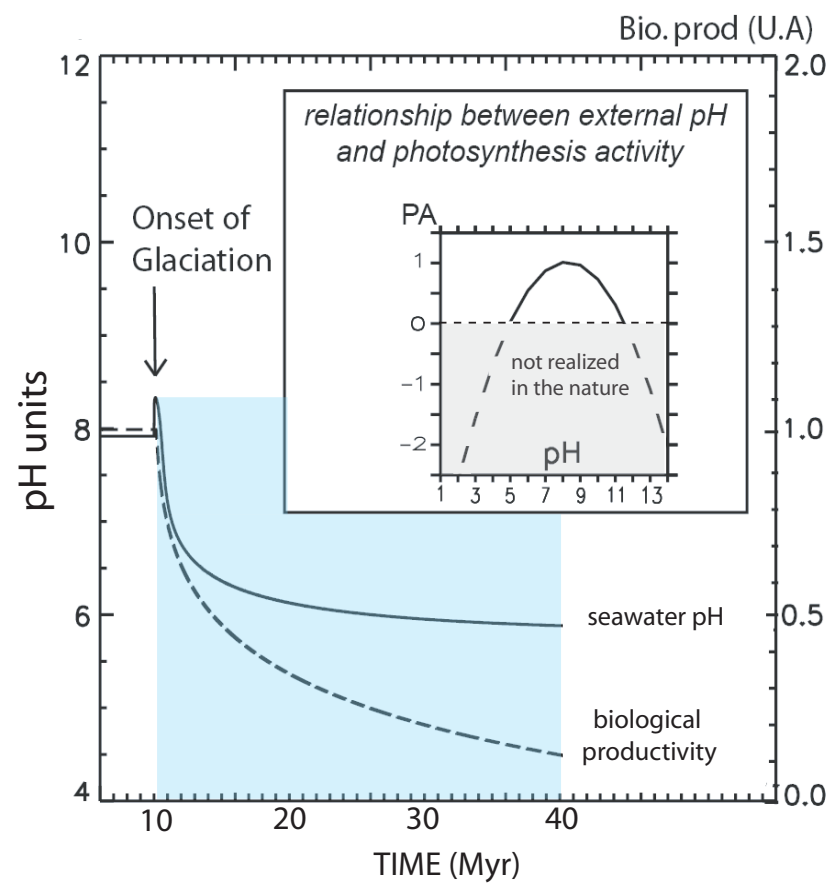

Fig. 10. Photosynthetic activity as function of a long-lived acidification of seawater. The blue bland represents the glaciation duration.

atmospheric $\mathrm{CO}_{2}$ is dissolved into the ocean, atmospheric $\mathrm{CO}_{2}$ level reaches 0.26 bar in only $7 \mathrm{Myr}$ instead of $30 \mathrm{Myr}$ (Fig. 11). At the termination of the glaciation, the massive atmospheric $\mathrm{CO}_{2}$ dissolution induces huge and rapid perturbation for $\mathrm{pH}$, dropping from 8 to 6 in only $10 \mathrm{kyr}$. In this context the oceanic $\mathrm{pH}$ is not buffered by the carbonate weathering because the atmospheric carbon dissolution rate in waters is faster and much more important. Therefore an isolated ocean is not a solution to reduce environmental perturbation in the aftermath of the glaciation, since post-glacial modifications are even stronger compared to a simulation where the ocean and atmosphere are kept in contact all along the glaciation.

Many other uncertainties still remain. One of the most important is the behaviour of weathering fluxes during the deglaciation. We have extrapolated to the super greenhouse climate parametric laws describing $\mathrm{CO}_{2}$ consumption through continental silicate weathering as a function of air temperature and runoff that were estimated for the present day climatic conditions (Oliva et al., 2003). As a result, silicate weathering rises 7 times above its present day value, and controls the rate at which the super greenhouse climate is finally relaxed. This is a first order study, and future work should use more complex model for estimating weathering rates. For carbonate rocks, we used a simple thermodynamic model assuming equilibrium of the continental waters with atmospheric $\mathrm{CO}_{2}$ at the model air temperature (Donnadieu et al., 2006). Although this method also suffers from poorly
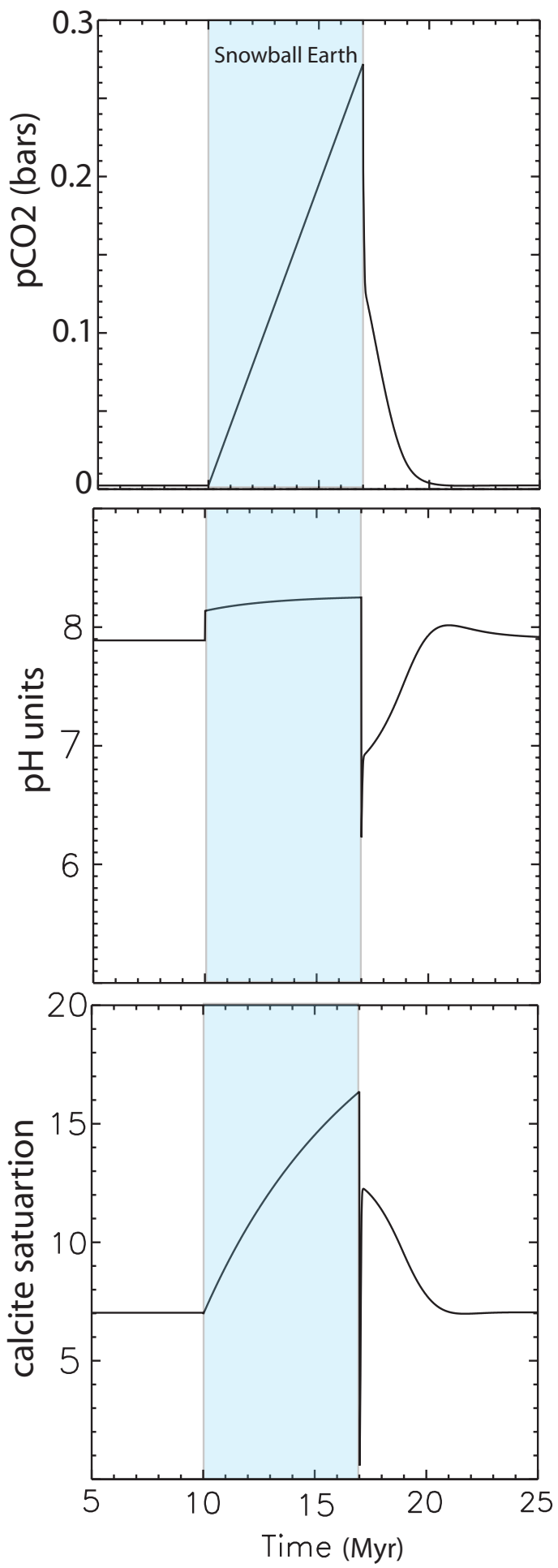

Fig. 11. Seawater modifications with an ocean isolated from the atmosphere. The blue bland represents the glaciation duration.

constrained parameters, such as the area of carbonate outcrops by the time of the deglaciation, it is more efficient than extrapolating parametric laws calibrated for present day 
conditions. A thermodynamic and kinetic method might be similarly applied to estimate silicate weathering rates in future studies.

Finally, the accumulation of cap dolostones is still problematic. Since mid-ocean ridges act as huge rock-fluid ion exchange system for $\mathrm{Ca}^{2+}$ and $\mathrm{Mg}^{2+}\left(\mathrm{Ca}^{2+}\right.$ being released to the fluid and $\mathrm{Mg}^{2+}$ being consumed by the conversion of oceanic basalt into amphibolites), then without any inputs from rivers, the $\mathrm{Mg} / \mathrm{Ca}$ ratio of seawater only depends on the hydrothermal activity. Our model simulates that the ocean become calcitic $(\mathrm{Mg} / \mathrm{Ca}$ ratio 1.4$)$ just before the deglaciation suggesting that carbonates immediately capping the glacial deposits should be calcite. However geological records show that the carbonate minerals precipitated first are primary dolomite $\left(\mathrm{Ca}_{0.5} \mathrm{Mg}_{0.5} \mathrm{CO}_{3}\right)$, indicating a rather high $\mathrm{Mg} / \mathrm{Ca}$ ratio in seawater at the time of deposition. Therefore the seawater composition must have deeply changed in the direct aftermath of the glaciation to allow precipitation of primary dolomite. The barite layer observed at the dolostonelimestone contact in several locations (Hoffman et al., 2007) may reflect this drastic change, when deep seawaters enriched in $\mathrm{Ba}^{2+}$, but depleted in sulphate (Hurtgen et al., 2006) are mixed with shallow waters coming from the post glacial runoff enriched in sulphate. The upwelling of low sulphate waters may have facilitated the dolomite precipitation (Baker and Kastner, 1981) despite the low $\mathrm{Mg} / \mathrm{Ca}$ ratio at the melting of the snowball. However estimates of the dolomite abiotic precipitation rate (Pokrovsky, 2001) shows that the kinetics of the reaction is by far too slow to account for the cap dolostone accumulation in a short time-span. Obviously, some cap dolostones facies were accumulated through the mediation of microbial activity, as they contain non negligible amount of organic matter (Elie et al., 2007). Present day area of dolomite accumulation are located in dysoxic environment and in the presence of sulphate reducing bacteria only, at rates potentially much faster than abiotic precipitation rate.

Because of this complexity, we have to assume that cap dolostones precipitation rate behaves as calcite precipitation rates, which is a critical but unavoidable assumption. The enigma of the dolostone precipitation in the aftermath of the snowball will not be solved until present day analog have been fully explored and understood.

\section{Conclusions}

During a global glaciation, the sea-ice growth reduces the oceanic life habitat and the population size of species depending on the light availability. We show that the dissolution of large amount of atmospheric $\mathrm{CO}_{2}$ into the ocean through cracks progressively acidifies the ocean down to $\mathrm{pH}$ 6 , accounting for the buffering effect of seafloor basalt dissolution. Coevally overturning reduction and oxygen consumption by hydrothermal vents produce a dysoxic ocean at the surface and anoxic at depth. Furthermore, dissolution of seafloor carbonates is not efficient enough to prevent the glacial ocean to become rapidly undersaturated with respect to carbonate minerals.

Once the atmospheric $\mathrm{CO}_{2}$ threshold for the melting of the snowball Earth is reached, the exospheric system undergoes rapid and dramatic changes. During the first $20 \mathrm{kyr}$, the ocean becomes warm, hypoxic, and remains too acidic and undersaturated to allow for sedimentary carbonate accumulation. Then the ocean becomes saturated enough and cap carbonates accumulation is eventually allowed. Starting with a calculated $\delta^{13} \mathrm{C}$ of -2 , their isotopic signature falls to -4 within the first $100 \mathrm{kyr}$, then goes back to the pre-glacial of +4 within $2 \mathrm{Ma}$. This sequence suggests a rather long time span for cap carbonate accumulation (about $400 \mathrm{kyr}$ ).

The most important environmental stress for life does not occur during the glaciation event itself, but rather during the onset and removal of the super greenhouse effect in the aftermath of the glaciation. Indeed, $\mathrm{pH}$ decrease from 8 to 6 during the snowball event spans about $4 \mathrm{Myr}$, mainly occurring during the early stages of the glacial event. But $\mathrm{pH}$ comes back from 6 to 8 within $20 \mathrm{kyr}$ during the super greenhouse effect, together with a sharp increase in temperature and the development of widespread anoxia.

The aim of this study was to quantify the perturbations in the global biogeochemical cycles during and in the direct aftermath of a global "snowball" glaciation. We thus postulate that the snowball glaciations did occur in the Neoproterozoic, and explore their consequences in terms of seawater chemistry. If one of the conclusions reached in this modelling study and field observations are contradictory, two questions should be logically asked: (1) is the modelling realistic enough to account for the consequences of a snowball Earth, and, if the answer is yes, (2) did the snowball Earth occur? We feel that improvements in our understanding and modelling of the Earth system are required before being able to answer even the first question.

Acknowledgements. This work was achieved thanks to the financial support of the CEA and the INSU/CNRS through the Eclipse program and in collaboration with the Climate Systems Center, which receives funding from the US National Science Foundation under grant ATM-0121028. A. Nédélec (LMTG, Toulouse) and G. Halverson (Adelaide University) are acknowledged for helpful discussions. The authors wish to thank A. Ridgwell, F. A. Corsetti, anonymous reviewers, and the editor for their constructive remarks.

Edited by: T. W. Lyons 


\section{References}

Alt, J. C. and Teagle, D. A. H.: The uptake of carbon during alteration of ocean crust, Geochim. Cosmochim. Ac., 63(10), 15271535, 1999.

Baker, P. A. and Kastner, M.: Constraints On The Formation Of Sedimentary Dolomite, Science, 213(4504), 214-216, 1981.

Berner, R. A. and Kothavala, Z.: GEOCARB III: A revised model of atmospheric CO2 over phanerozoic time, Am. J. Sci., 301(2), 182-204, 2001.

Bodiselitsch, B., Koeberl, C., Master, S., and Reimold, W. U.: Estimating duration and intensity of Neoproterozoic snowball glaciations from Ir anomalies, Science, 308(5719), 239-242, 2005.

Bown, P. R., Lees, J. A, and Young, J. R.: Calcareous nannoplankton evolution and diversity through time, in: CoccolithophoresFrom molecular processes to global impact, edited by: Thierstein, H. R. and Young, J. R., 481-508, 2004.

Brady, P. V. and Gislason, S. R.: Seafloor weathering controls on atmospheric $\mathrm{CO} 2$ and global climate, Geochim. Cosmochim. Ac., 61(5), 965-973, 1997.

Canfield, D. E., Poulton, S. W., and Narbonne, G. M.: LateNeoproterozoic deep-ocean oxygenation and the rise of animal life, Science, 315(5808), 92-95, 2007.

Catling, D. C. and Claire, M. W.: How Earth's atmosphere evolved to an oxic state: A status report, Earth Planet. Sc. Lett., 237(1-2), 1-20, 2005.

ClimT: CliMT is developed by Rodrigo Caballero, with contributions from Jonathan Mitchell and Mike Steder. It initiated as a project of the Climate Systems Center at the Department of the Geophysical Sciences, University of Chicago, with funding from NSF Information Technology Research grant ATM0121028, 2006.

Cogné, J. P. and Humler, E.: Temporal variation of oceanic spreading and crustal production rates during the last $180 \mathrm{My}$, Earth Planet. Sc. Lett., 227(3-4), 427-439, 2004.

Coleman, J. R. a. C. B.: Inorganic carbon Accumulation and Photosynthesis in a Blue-green Alga as a Function of external pH, Plant Physiol., 67, 917-921, 1981.

Condie, K. C. and Robert E. S.: Origin and Evolution of Earth, Principles of Historical Geology, p. 498, 1998.

Condon, D., Zhu, M. Y., Bowring, S., Wang, W., Yang, A. H., and Jin, Y. G.: U-Pb ages from the neoproterozoic Doushantuo Formation, China, Science, 308(5718), 95-98, 2005.

Corsetti, F. A., Awramik, S. M. and Pierce, D.: A complex microbiota from snowball Earth times: Microfossils from the Neoproterozoic Kingston Peak Formation, Death Valley, USA, P. Natl. Acad. Sci. USA, 100(8), 4399-4404, 2003.

Corsetti, F. A., Olcott, A. N., and Bakermans, C.: The biotic response to Neoproterozoic snowball earth, Palaeogeogr. Palaeocl., 232, 114-130, 2006.

Dessert, C., Dupré, B., Gaillardet, J., Francois, L. M., and Allégre, C. J.: Basalt weathering laws and the impact of basalt weathering on the global carbon cycle, Chem. Geol., 202(3-4), 257-273, 2003.

Donnadieu, Y., Fluteau, F., Ramstein, G., Ritz, C. and Besse, J.: Is there a conflict between the Neoproterozoic glacial deposits and the snowball Earth interpretation: an improved understanding with numerical modeling, Earth Planet. Sc. Lett., 208(1-2), 101-112, 2003.
Donnadieu, Y., Goddéris, Y., Pierrehumbert, R., Dromart, G., Fluteau, F., and Jacob, R.: A GEOCLIM simulation of climatic and biogeochemical consequences of Pangea breakup, Geochem. Geophy. Geosy., 7, 1-21, 2006.

Donnadieu, Y., Goddéris, Y., Ramstein, G., Nédélec, A., and Meert, J.: A "snowball Earth" climate triggered by continental break-up through changes in runoff, Nature, 428(6980), 303-306, 2004.

Elderfield, H. and Schultz, A.: Mid-ocean ridge hydrothermal fluxes and the chemical composition of the ocean, Annu. Rev. Earth Pl. Sc., 24, 191-224, 1996.

Elie, M., Nogueira, A. C. R., Nédélec, A., Trindade, R. I. F., and Kenig, F.: Biodiversity collapse and red algal bloom in the aftermath of the Marinoan Snowball Earth, Terra Nova, 9(5), 303308, 2007.

Eyring, H.: The activated complex in chemical reactions, J. Chem. Phys., 3, 107-115, 1937.

Fike, D. A., Grotzinger, J. P., Pratt, L. M., and Summons, R. E.: Oxidation of the Ediacaran Ocean, Nature, 444(7120), 744-747, 2006.

Gaillardet, J., Dupré, B., Louvat, P., and Allegre, C. J.: Global silicate weathering and $\mathrm{CO} 2$ consumption rates deduced from the chemistry of large rivers, Chem. Geol., 159(1-4), 3-30, 1999.

Garrett, C.: Mixing with latitude, Nature, 422(6931), 477-478, 2003.

Goddéris, Y., Francois, L. M., Probst, A., Schott, J., Moncoulon, D., Labat, D., and Viville, D.: Modelling weathering processes at the catchment scale: The WITCH numerical model, Geochim. Cosmochim. Ac., 70(5), 1128-1147, 2006.

Goddéris, Y., Francois, L. M., and Veizer, J.: The early Paleozoic carbon cycle, Earth Planet. Sc. Lett., 190(3-4), 181-196, 2001.

Goddéris, Y. and Joachimski, M. M.: Global change in the Late Devonian: modelling the Frasnian-Famennian short-term carbon isotope excursions, Palaeogeogr. Palaeocl., 202(3-4), 309-329, 2004.

Goodman, J. C. and Pierrehumbert, R. T.:, 2003. Glacial flow of floating marine ice in "Snowball Earth", J. Geophys. Res.Oceans, 108(C10), 3308, doi:10.1029/2002JC001471, 2003.

Grey, K., Walter, M. R., and Calver, C. R.: Neoproterozoic biotic diversification: Snowball Earth or aftermath of the Acraman impact?, Geology, 31(5), 459-462, 2003.

Halverson, G. P., Maloof, A. C. and Hoffman, P. F.: The Marinoan glaciation (Neoproterozoic) in northeast Svalbard, Basin Res., 16(3), 297-324, 2004.

Higgins, J. A. and Schrag, D. P.: Aftermath of a snowball Earth, Geochem. Geophy. Geosy., 4(3), 1-20, 2003.

Hoffman, P. F., Halverson, G. P., Domack, E. W., Husson, J. M., Higgins, J. A., and Schrag, D. P: Are basal Ediacarian (635 Ma) post-glacial "cap-dolostones" diachronous?, Earth Planet. Sc. Lett., 258(1-2), 114-131, 2007.

Hoffman, P. F., Kaufman, A. J., Halverson, G. P., and Schrag, D. P.: A Neoproterozoic snowball earth, Science, 281(5381), 13421346, 1998.

Hoffman, P. F. and Schrag, D. P.: The snowball Earth hypothesis: testing the limits of global change, Terra Nova, 14(3), 129-155, 2002. 
Hurtgen, M. T., Halverson, G. P., Arthur, M. A., and Hoffman, P. F.: Sulfur cycling in the aftermath of a 635-Ma snowball glaciation: Evidence for a syn-glacial sulfidic deep ocean, Earth Planet. Sc. Lett., 245(3-4), 551-570, 2006.

Kasting, J. F.: Theoretical Constraints On Oxygen And CarbonDioxide Concentrations In The Precambrian Atmosphere, Precambrian Res., 34(3-4), 205-229, 1987.

Kerrick, D. M.: Present and past nonanthropogenic $\mathrm{CO} 2$ degassing from the solid Earth, Rev. Geophys., 39(4), 565-585, 2001.

Kirschvink, J. L.: Late proterozoic low-latitude glaciation: the snowball earth, in: The Proterozoic Biosphere, edited by: Schopf, J. W. and Klein, C., 51-52, 1992.

Knoll, A. H.: Life on a Young Planet, 277 pp., Princeton University Press, 2003.

Kuznetsova, K. I.: The first genera of planktonic foraminifers: Morphogenesis, development, and expansion in the Jurassic, Paleontol. J., 37(5), 472-485, 2003.

Le Guerroué, E., Allen, P. A., and Cozzi, A.: Chemostratigraphic and sedimentological framework of the largest negative carbon isotopic excursion in Earth history: The Neoproterozoic Shuram Formation (Nafun Group, Oman) (vol 146, pg 68, 2006), Precambrian Res., 153(3-4), 262-265, 2007.

Le Hir, G., Goddéris, Y., Donnadieu, Y., and Ramstein, G.: Scenario for the evolution of atmospheric pCO2 during a snowball Earth, Geology, 36, 47-50, 2008.

Leather, J., Allen, P. A., Brasier, M. D., and Cozzi, A.: Neoproterozoic snowball earth under scrutiny: Evidence from the Fiq glaciation of Oman, Geology, 30(10), 891-894, 2002.

Lynch-Stieglitz, J., Adkins, J. F., Curry, W. B., Dokken, T., Hall, I. R., Herguera, J. C., Hirschi, J. J. M., Ivanova, E. V., Kissel, C., Marchal, O., Marchitto, T. M., McCave, I. N., McManus, J. F., Mulitza, S., Ninnemann, U., Peeters, F., Yu, E. F., and Zahn, R.: Atlantic meridional overturning circulation during the Last Glacial Maximum, Science, 316(5821), 66-69, 2007.

McKay, C. P.: Thickness of tropical ice and photosynthesis on a snowball Earth, Geophys. Res. Lett., 27(14), 2153-2156, 2000.

O Cofaigh, C., Evans, J., Dowdeswell, J. C., and Larter, R. D.: Till characteristics, genesis and transport beneath Antarctic paleo-ice streams, J. Geophys. Res., 112, F03006, doi:10.1029/2006JF000606, 2007.

Olcott, A., Sessions, A., Corsetti, F., Kaufman, A., and De Oliviera, T.: Biomarker Evidence for Photosynthesis During Neoproterozoic Glaciation, Science Express, 2005.

Oliva, P., Dupré, B., Martin, F., and Viers, J.: The role of trace minerals in chemical weathering in a high-elevation granitic watershed (Estibere, France): Chemical and mineralogical evidence, Geochim. Cosmochim. Ac., 68(10), 2223-2243, 2004.

Opdyke, B. N. and Walker, J. C. G.: Return Of The Coral-Reef Hypothesis - Basin To Shelf Partitioning Of $\mathrm{Caco} 3$ And Its Effect On Atmospheric Co2, Geology, 20(8), 733-736, 1992.

Pierrehumbert, R. T.: High levels of atmospheric carbon dioxide necessary for the termination of global glaciation, Nature, 429(6992), 646-649, 2004.

Pierrehumbert, R. T.: Climate dynamics of a hard Snowball Earth, J. Geophys. Res., 110, D01111, doi:10.1029/2004JD005162, 2005.
Pokrovsky, O. and Schott, J.: Kinetics and Mechanism of dolomite dissolution in neutral to alkaline solutions revisited, Am. J. Sci., 301, 597-626, 2001.

Pollard, D. and Kasting, J. F.: Snowball Earth: A thin-ice solution with flowing sea glaciers, J. Geophys. Res.-Oceans, 110(C7), C07010, doi:10.1029/2004JC002525, 2005.

Price, P. B. and Sowers, T.: Temperature dependence of metabolic rates for microbial growth, maintenance, and survival, P. Natl. Acad. Sci. USA, 101(13), 4631-4636, 2004.

Ridgwell, A. and Zeebe, R. E.: The role of the global carbonate cycle in the regulation and evolution of the Earth system, Earth Planet. Sc. Lett., 234(3-4), 299-315, 2005.

Rieu, R., Allen, P. A., Plotze, M., and Pettke, T.: Climatic cycles during a Neoproterozoic "snowball" glacial epoch, Geology, 35(4), 299-302, 2007.

Shield, G. A.: Neoproterozoic cap carbonates: a critical appraisal of existing models and the plumeworld hypothesis, Terra Nova, 17(4), 299-310, 2005.

Tranter, M., Huybrechts, P., Munhoven, G., Sharp, M. J., Brown, G. H., Jones, I. W., Hodson, A. J., Hodgkins, R., and Wadham, J. L.: Direct effect of ice sheets on terrestrial bicarbonate, sulphate and base cation fluxes during the last glacial cycle: minimal impact on atmospheric CO2 concentrations, Chemical Geology, 190(14), 33-44, 2002.

Trindade, R. I. F., Font, E., D’Agrella, M. S., Nogueira, A. C. R., and Riccomini, C.: Low-latitude and multiple geomagnetic reversals in the Neoproterozoic Puga cap carbonate, Amazon craton, Terra Nova, 15(6), 441-446, 2003.

Vincent, W. F. and Howard-Williams, C.: Life on snowball Earth, Science, 287(5462), 2421-2421, 2000.

Walker, L., Wilkinson, B. H., and Ivany, L. C.: Continental drift and Phanerozoic carbonate accumulation in shallow-shelf and deepmarine settings, J. Geol., 110(1), 75-87, 2002.

Wallmann, K.: Feedbacks between oceanic redox states and marine productivity: A model perspective focused on benthic phosphorus cycling, Global Biogeochem. Cy., 17(3), 1084, doi:10.1029/2002GB001968, 2003.

Warren, S. G., Brandt, R. E., Grenfell, T. C., and McKay, C. P.: Snowball Earth: Ice thickness on the tropical ocean, J. Geophys. Res.-Oceans, 107(C10), 3167, doi:10.1029/2001JC001123, 2002.

Yin, L. M., Zhu, M. Y., Knoll, A. H., Yuan, X. L., Zhang, J. M., and $\mathrm{Hu}, \mathrm{J} .:$ Doushantuo embryos preserved inside diapause egg cysts, Nature, 446(7136), 661-663, 2007.

Young, G. M.: Neoproterozoic Glaciation In The Broken-Hill Area, New-South-Wales, Australia, Geol. Soc. Am. Bull., 104(7), 840850, 1992.

Zhang, R., Follows, M. J., Grotzinger, J. P., and Marshall, J.: Could the Late Permian deep ocean have been anoxic?, Paleoceanography, 16(3), 317-329, 2001.

Zhou, C. M., Tucker, R., Xiao, S. H., Peng, Z. X., Yuan, X. L., and Chen, Z.: New constraints on the ages of neoproterozoic glaciations in south China, Geology, 32(5), 437-440, 2004. 